\title{
Critical Pedagogy: A Key Factor for Improvement of Iranian EFL Learners' Self-Regulation and Writing Ability
}

\author{
Neda Mohammadi (Ghouzani) \\ Department of English Islamic Azad University (IAU) \\ Torbat-e-Heydareih Branch, Iran \\ Email: Neda.Mohammadi.TEFL@Gmail.com \\ Khalil Motallebzadeh \\ Department of English Islamic Azad University (IAU) \\ Torbat-e-Heydareih Branch, Iran \\ Email:kmotallebz@gmail.com \\ Hamid Ashraf \\ Department of English Islamic Azad University (IAU) \\ Torbat-e-Heydareih Branch, Iran \\ Email: hamid.ashraf.elt@gmail.com
}

Received: 10-01-2014

doi:10.7575/aiac.ijalel.v.3n.4p.46
Accepted: 04-03-2014

Published: 01-07-2014

URL: http://dx.doi.org/10.7575/aiac.ijalel.v.3n.4p.46

\begin{abstract}
As Keesing-Style (2003) puts out, although the concept of critical pedagogy (CP) has been proposed for three decades, it has not been employed in the educational settings. This study investigated the effect of employing critical pedagogy on the improvement of Iranian EFL learners' self-regulation and writing skill. To achieve this goal, a group of 60 female EFL students (aged between 14 to 25 years old) participated in the free paragraph writing course based on their scores on a Writing Placement Test and a Self-Regulation Questionnaire. Participants were divided into two control $(\mathrm{N}=30)$ and experimental $(\mathrm{N}=30)$ groups. The learners in experimental group were taught paragraph writing via $\mathrm{CP}$. In contrast, the learners in control group were taught paragraph writing through traditional pedagogy. In both control and experimental groups, two tests including a Writing Placement Test and a Self-Regulation Questionnaire (SRQ) were administered before and after the treatment to check the participants' progress or regress. After a five-month study, twenty sessions of treatment, it was revealed that applying CP can significantly affect ( $\operatorname{sig}=.000)$ Iranian upperintermediate female EFL learners' writing skill. Meanwhile, implementation of CP greatly reinforced $(\operatorname{sig}=.003)$ the learners' self-regulation skill.
\end{abstract}

Keywords: critical pedagogy, self-regulation, paragraph writing, zone of proximal development (ZPD), traditional pedagogy

\section{Introduction}

New ELT perspectives remind the significance of contextualizing English learning and considering cultural and social contexts in which the foreign language is taught. In other words, to come up with effective foreign language outcomes, individual's life experiences and their social beings should be integrated to educational practices. In addition, Educational approaches ask ELT educators to act as a mentor and help learners to promote critical language awareness. Therefore, critical pedagogy (CP) was found as an exhaustive system of learning through which learners' critical consciousness, self-regulation and autonomy, individuality, and learning achievements were promoted. Critical pedagogy highlights Vygotsky's theory of the zone of proximal development (ZPD) in which people learn materials with the help of others. Learners are provided with a learning process in which teacher and students negotiate whole of the class procedures, material, and grading process (Moreno-Lopez, 2005).

Although the new language teaching approaches emphasize on the development of more critical approaches for improving language learning, there have been little changes in educational systems, and schools usually perpetuate traditional approaches in language classroom settings. The educational systems determine particular dispositions in students and teachers so that they are expected to behave in their predetermined roles of the teacher as the knowledge broker and the student as the receiver of knowledge.

Also, in recent years, some researchers such as Mohebi, Beykmohammadi, and Farsani (2011); Alsamadani (2010); Cuenca-Sanchez (2008); Majid (2007); Graham (2006); Ruan (2005) have emphasized on the significant role of individuals' self-regulatory strategies in promoting their language learning achievements. However, in the language classroom settings, the instructor does not raise students' motivation to regulate their own learning. In fact, the language 
teachers are not trained how to activate both their own self-regulatory processes and strategies and those of the students'.

Facing the problems mentioned above, the researchers try to investigate to what extent applying critical pedagogy promotes students' self-regulation skill and their writing ability.

\section{Literature Review}

According to Aghagolzadeh and Davari (2012), since the beginning years of 1990s, the advent of a critical intellectual change in applied linguistics has not only questioned the mainstream ELT but also has significantly proposed CP as an alternative and effective approach in ELT. Aghagolzadeh and Davari (2012, p. 979) have discussed that the rationale for using CP in ELT includes the main factors of " (a) socio-political and ideological factors, (b) the issue of culture, (c) local as well as global topics." From critical pedagogy standpoint, teachers and learners should promote English learning in a way to achieve critical spirit that leads to achieving of two concepts of conscious awareness and critical awareness (Wallace, 1997). According to Izadinia (2012) and Pennycook (1995), In ELT field, although there has been a little attempt to evoke critical awareness regarding English, from a behavioristic to a pragmatic orientation, the main attention has been paid to language teaching methodologies through which what happens in the classroom is investigated. As a result of this over-simplistic attitude toward the diffusion of English globally, English language is considered as the "natural" result of globalization, a "neutral" tool through which people can communicate, and a "beneficial" language because it promotes inter-national or intra-national relations (Pennycook, 1995, p. 83). This perspective ignores the "postcolonialism and neocolonialism" spread of English. Moreover, English is viewed as an "ahistorical and apolitical entity in a singular reality" (Byean, 2011, p. 38). From a poststructuralist perspective and a critical pedagogy standpoint, language represents the social existence and it has something to say beyond its abstract structure. Keeping with this perspective, Peirce (1989) considers English as a language which emphasizes on meaning, power, and human's goal. Thus, English is not regarded neutral anymore.

Giroux (1981) emphasizes on repositioning the education. Unlike traditional pedagogy which focuses on historical continuities, critical pedagogy (CP) encourages educators to a mode of analysis, tensions, and discontinuities in history, all of which reveal both the significance of human agency and the gap between society which exists now and the society which might exist.. Giroux (1981) believes that the most significant feature of critical pedagogy is the principle of resistance which highlights Freire's belief (1970) that traditional pedagogy prevents teachers to grow the concept of resistance in the students' minds. This resistance leads to both the process of students' empowerment in educational system and their social life. Giroux (1983) and Fredricks (2007) also believe that schools are required to highlight diverse cultures. There is less emphasis on cultural concerns. In fact, there should be implemented programs that equalize education for different groups of people with diverse ideas, concepts, and cultures.

Critical Pedagogy can be defined as an approach to teaching and curriculum that "seeks to understand and critique the historical and sociopolitical context of schooling and to develop pedagogical practices that aim not only to change the nature of schooling, but also the wider society" (Pennycook, 1990, P. 24). Applying CP in ELT classrooms, Byean (2011) comes to the conclusion that CP positively affects the learning process since it considers all facets of educational practices in a society including not only curriculum, syllabus, materials, contents, classroom methodologies, and evaluation process, but also sociopolitical, sociohistorical, economical, and cultural aspects of a society. Also, Motallebzadeh and Askari's (2009) study revealed a positive effect of CP on Iranian intermediate EFL learners' language ability and their self-esteem as well. But this study is going to investigate the effect of CP on Iranian EFL learners' self-regulation and writing ability.

To achieve the object of this study, the following research questions have been raised.

Q1. Does critical pedagogy have any significant effect on Iranian upper-intermediate EFL learners' self-regulation?

Q2.Does critical pedagogy have any significant effect on Iranian upper-intermediate EFL learners' paragraph writing skill?

In order to answers to the above questions, the following null hypotheses are proposed:

H01. Critical pedagogy does not have any significant effect on Iranian upper-intermediate EFL learners' self-regulation.

H02. Critical pedagogy does not have any significant effect on Iranian upper-intermediate EFL learners' paragraph writing skill.

\section{Methodology}

\subsection{Participants and Setting}

This project involved two upper-intermediate English writing courses that were taught in two private language institutes in Iran. The number of the participants who took the Writing Placement Test was 83 female students in one of the institutes. Also, 77 female learners took the Writing Placement Test in another institute. Finally, two groups of 30 female students (one group in each institute) were selected as the participants of the study. One group was considered as the experimental group and the other group was considered as control group. The participants' age in both the control and the experimental groups ranged from 14 to 25 , and all the participants of the study were Persian native speakers who were studying English as a foreign language and who never lived in a foreign country. 


\subsection{Instrumentations}

To collect the required data, Lesley, Hanson, and Zukowski's (2005) Writing Placement Test Form C of the third edition of the Interchange/Passages Evaluation Package and Self-Regulation Questionnaire (SRQ) were applied. The Interchange Writing Placement Test required the students to write a paragraph about one of the three topics offered to them within 30 minutes. The students' writings in both experimental and control groups were rated by three raters that were to be involved in the scoring of Writing Placement Test in order to add valuable input to the process. The raters rated the students' writing based on the public (general) version of the IELTS Writing Band Descriptors, Task 2. The inter-rater reliability of the scores was estimated via calculating the average score of the raters'. The average score of the three raters' scores was compared to the IELTS Writing Band Descriptors, Task 2, in which the suitable band for upperintermediate level was between 6 and 7. The same Writing Placement Test were administered as tests of homogeneity, as pretests, and as posttests in both control and experimental groups.

The Self-Regulation Questionnaire (SRQ) was developed by Brown, Miller, and Lawendowski (1999). The SRQ contained 63 items that were answered on a 5-point Likert scale. Reliability of the SRQ was great. Test-retest reliability for the total SRQ was high $(r=.94, P<.0001)$. Internal consistency of the scale was also high $(\alpha=.91)$. The SRQ was scored (in both the experimental and the control groups) based on the scoring guidelines developed by Brown et al. (1999). The learners took the same SRQ as pretests, and as posttests in both control and experimental groups.

\subsection{Procedure}

The researchers decided to do the research in two language institutes in Iran. The administrators of both institutes agreed on holding a free twenty - session paragraph writing course. The students who registered in the course were required to take Lesley et al.' s (2005) Writing Placement Test Form C of the third edition of the Interchange / Passages Evaluation Package. Then, among the learners who took the Interchange Writing Test in two institutes, those who passed IELTS Writing Band Descriptors, Task 2 with scores of between 6 and 7 for upper-intermediate level were chosen. Finally, those learners who got 6 , between 6 and 7, and 7 were also administered a self-regulation questionnaire, and among them, those who were homogenous regarding self-regulatory processes were chosen as the subjects of the study (30 learners in each institute). It is worth mention that the same Writing Placement Test and SRQ were considered as tests of homogeneity, as pretests, and as posttests in both control and experimental groups. The learners in control group were taught via traditional pedagogy and the students in experimental group received treatment through critical pedagogy.

Since critical pedagogy and practice were used in experimental group, the focus was on sharing power between the teacher and the students, considering the students' individual voices, and taking account of the learners' social, cultural and political life experiences. To accomplish CP in experimental group classroom, the following procedures were carried out.

In order to warrant that the students in experimental group covered the same materials as the students in control group, the institute syllabus was applied while the teacher and the students in experimental group were free to change the syllabus based on their needs. Accordingly, the students in the experimental group had the same textbooks as the students in control group, but they just applied the books as a guideline and did not follow their contents step by step. In fact, these were the teacher and the students who negotiated together and decided what to be taught first, second, and so on. Also, the learners always wrote about what they were interested in not what had been determined by the book.

Every decision in the class was made according to the opinions of the majority of the class participants including the teacher and the students. Accordingly, to provide an opportunity in which the participants could share their ideas, and to facilitate the process of writing, teacher and students brainstormed on a topic chosen by the students themselves. Among the paragraphs written by the learners, two or three of the students' papers were randomly selected to discuss the new lesson over them. The students' papers were gathered for the purpose of teacher's comments later on. After receiving comments from the teacher, the students were let to revise their paragraphs as many times as they liked in order to have the opportunity to reach "A" quality of the written work. In this way, the learners were provided with a situation in which learning improvement was occurred as a process and not an end.

The students participated in assessing their class performance and grading process through negotiating with the teacher. Teacher- student's negotiation follows a contract system (adapted from Shor, 1996, p. 77, cited in Moreno-Lopez, 2005) which had been partially changed based on the learners' needs and interests.

In control group, the institute established syllabus was followed without any modification. Also, the textbooks (Guided Paragraph Writing by TC Jupp and Milne (1972) and Paragraph Development developed by Arnaudet and Barrett (1990)) were followed step by step. During the whole semester, teacher was the full authority in the classroom, and the students were passive recipient of knowledge. Every session, teacher taught the predetermined materials, and when the students wrote a paragraph, teacher corrected it and did not give any comments on the learners' writings for the purpose of their reflection later on.

After treatment, the students in both the control and experimental groups took the same two pretests as the posttests. Thus, the design of the study was pretest posttest design. According to what mentioned, a quasi-experimental, intact group, pretest and posttest design was used in this study. 


\section{Results and Discussions}

After collecting the required data based on the Writing Placement Test and SRQ, the analysis of data was conducted to test the hypothesis of the present study.

To investigate the normality of the data obtained from the third edition of Interchange/Passages Writing Placement Test in both control and experimental groups, One-Sample Kolmogorov-Smirnov Test was applied.

Table 1. One-Sample Kolmogorov-Smirnov Test for Determining the Normality of the Data of Writing Test

\begin{tabular}{lcc}
\hline & CO & EXP \\
\hline $\mathrm{N} \quad$ & 60 & 60 \\
Normal Parameters ${ }^{\mathrm{a} . \mathrm{b}}$ & & \\
$\quad$ Mean & 6.3433 & 6.7183 \\
$\quad$ Std. Deviation & .33967 & .49179 \\
Most Extreme & & \\
$\quad$ Absolute & .367 & .300 \\
Differences & & \\
$\quad$ Positive & .367 & .219 \\
$\quad$ Negative & -.166 & -.300 \\
Kolmogorov-Smirnov Z & 2.846 & 2.323 \\
Asymp. Sig. (2-tailed) & .000 & .000 \\
\hline
\end{tabular}

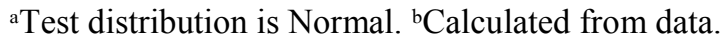

As it is shown in Table 1, the results of One-Sample Kolmogorov-Smirnov Test show that the data achieved from the writing test are not normal either in control $(p=.000<.05)$ or in experimental $(p=.000<.05)$ groups. Consequently, to investigate the significance of data obtained from writing test, NPar Tests including Mann-Whitney U Tests and Wilcoxon Signed Ranks Tests were applied.

Table 2. Wilcoxon Signed Ranks Test Statistics ${ }^{\mathrm{b}}$ for Pretest and Posttest of Writing Placement Test by Experimental Group

\begin{tabular}{lc}
\hline & $\begin{array}{c}\text { Writing test } \\
\text { Exp pre-Exp post }\end{array}$ \\
\hline$Z$ & $-.4 .418^{\mathrm{a}}$ \\
Asymp. Sig. (2-tailed) & .000 \\
\hline${ }^{\mathrm{a} B a s e d}$ on negative ranks. ${ }^{\mathrm{b}}$ Wilcoxon Signed Ranks
\end{tabular}

As the results of Table 2 illustrate, Wilcoxon Signed Rank Test reveals a statistically significant increase in the writing skill of the learners following participation in the five-month treatment via critical pedagogy, $\mathrm{z}=-.4 .41, \mathrm{p}=.000<.05$. This means that compared with the pretest, the students' scores of experimental group significantly has changed in the posttest showing that critical pedagogy affected the students' writings positively.

Table 3. Wilcoxon Signed Ranks Test Statistics ${ }^{\mathrm{b}}$ for Pretest and Posttest of Writing Placement Test by Control Group

\begin{tabular}{lc}
\hline & $\begin{array}{c}\text { Writing test } \\
\text { Co pre-Co post }\end{array}$ \\
\hline $\mathrm{Z}$ & $-2.310^{\mathrm{a}}$ \\
Asymp. Sig. (2-tailed) & .021 \\
\hline${ }^{\mathrm{a} B a s e d}$ on negative ranks. ${ }^{\mathrm{b}}$ Wilcoxon Signed Ranks.
\end{tabular}

As it can be seen from Table 3, a Wilcoxon Signed Ranks Test reveals no significant difference in the writing skill of the learners participating in the five-month study via traditional pedagogy, $\mathrm{z}=-.2 .31, \mathrm{p}=.021>.05$. This means that 
compared with the pretest, the students' scores of control group did not change in the posttest. Thus, based on the results of this study, traditional pedagogy did not affect the students' writing skill significantly.

Table 4. Mann-Whitney U Test Statistics ${ }^{\mathrm{a}}$ for

Pretest of Writing Placement Test by Groups

\begin{tabular}{lc}
\hline & $\begin{array}{c}\text { Writing test in } \\
\text { pretest }\end{array}$ \\
\hline Mann-Whitney U & 419.000 \\
Wilcoxon W & 884.000 \\
Z & -.498 \\
Asymp. Sig. (2-tailed) & .619 \\
\hline${ }^{a}$ Grouping Variable: GROUP. &
\end{tabular}

As shown in Table 4, Mann-Whitney U Test reveals no significant difference in the Writing Placement Test scores of control and experimental groups before treatment, $\mathrm{U}=419, \mathrm{z}=-.49, \mathrm{p}=.61>.05$. It demonstrates that the two groups were at the same level of homogeneity regarding their writing skill before treatment.

Table 5. Mann-Whitney U Test Statistics ${ }^{\mathrm{a}}$ for Posttest

of Writing Placement Test by Groups

\begin{tabular}{lc}
\hline & $\begin{array}{c}\text { Writing test in } \\
\text { posttest }\end{array}$ \\
\hline Mann-Whitney U & 72.000 \\
Wilcoxon W & 537.000 \\
$Z$ & -5.886 \\
Asymp. Sig. (2-tailed) & .000 \\
\hline${ }^{a}$ Grouping Variable: GROUP. &
\end{tabular}

Although the two groups of control and experimental were at the same level of writing skill in the pretest, the results of Mann Whitney U Test in Table 5 show a significant difference between the control and experimental groups after a five-month study, $U=72, z=-5.88, p=.000<.05$. Since on one hand, the writing skill of the control group did not change after a five-month study via traditional pedagogy (as shown in Table 3 ), and on the other hand, the writing skill of both control and experimental groups was at the same level at the beginning of the study (as indicated in table 4), it was easy to understand that the significant difference of writing skill between the control and experimental groups at their posttest ( as presented in Table 5 ) was because of the treatment (critical pedagogy) the students had in the experimental group; Table 2 also proved so. Thus, the null-hypothesis mentioning that "critical pedagogy does not have any significant effect on Iranian upper-intermediate EFL learners' writing skill" was rejected. The experimental group outperformed the control group on the posttest of writing test, and the results of this study show that CP did affect the students' writing skill positively.

To examine the normality of data achieved from self-regulation questionnaire developed by Brown et al. (1999), OneSample Kolmogorov-Smirnov Test was applied.

Table 6. One-Sample Kolmogorov-Smirnov Test for

Determining the Normality of Data of Self-Regulation Questionnaire

\begin{tabular}{lcc}
\hline & CO & EXP \\
\hline $\mathrm{N}$ & 60 & 60 \\
Normal Parameters ${ }^{\mathrm{a} . \mathrm{b}}$ & & \\
$\quad$ Mean & 222.80 & 213.18 \\
$\quad$ Std. Deviation & 30.914 & 32.169 \\
Most Extreme & & \\
$\quad$ Absolute & .105 & .106 \\
Differences & & \\
$\quad$ Positive & .074 & .106 \\
$\quad$ Negative & -.105 & -.063 \\
Kolmogorov-Smirnov Z & .810 & .821 \\
Asymp. Sig. (2-tailed) & .527 & .510 \\
\hline
\end{tabular}

aTest distribution is Normal. ${ }^{\mathrm{b}}$ Calculated from data. 
As illustrated in Table 6, the results of One-Sample Kolmogorov-Smirnov Test reveal that the data obtained from the self-regulation questionnaire are normal in both control $(\mathrm{p}=.52>.05)$ and experimental $(\mathrm{p}=.51>.05)$ groups. Consequently, to determine the statistical significance of the achieved data of self-regulation questionnaire, Independent-Samples T-Test and Paired-Samples T-Test were applied.

Table 7. Paired T-Test Pretest and Posttest of SRQ by Experimental Group

\begin{tabular}{|c|c|c|c|c|c|c|c|c|}
\hline & \multicolumn{5}{|c|}{ Paired Differences } & \multirow[b]{3}{*}{$\mathrm{T}$} & \multirow[b]{3}{*}{ Df } & \multirow[b]{3}{*}{ Sig.(2-tailed) } \\
\hline & \multirow[b]{2}{*}{ Mean } & \multirow[b]{2}{*}{$\begin{array}{c}\text { Std. } \\
\text { Deviation } \\
\end{array}$} & \multirow{2}{*}{$\begin{array}{l}\text { Std. Error } \\
\text { Mean }\end{array}$} & \multicolumn{2}{|c|}{$\begin{array}{c}95 \% \text { confidence interval } \\
\text { of the difference }\end{array}$} & & & \\
\hline & & & & lower & Upper & & & \\
\hline Exp. Group pre-post & -30.0667 & 18.75235 & 3.42369 & -37.0689 & -23.0644 & $\begin{array}{c}- \\
8.782\end{array}$ & 29 & .000 \\
\hline
\end{tabular}

Table 7 also displays a significant difference between the experimental group learners' SRQ scores in the pretest and posttest [t (29) $=-8.78, \mathrm{p}=.000$ (two-tailed)]. The mean increase in SRQ scores is -30.06 with a $95 \%$ confidence interval ranging from -37.06 to -23.06 . Thus, the students' scores prove that critical pedagogy has a positive effect on the students' self-regulation skill.

Table 8. Paired T-Test Pretest and Posttest of SRQ by Control Group

Paired Differences

\begin{tabular}{|c|c|c|c|c|c|c|c|c|}
\hline & \multirow[b]{3}{*}{ Mean } & \multirow[b]{3}{*}{$\begin{array}{c}\text { Std. } \\
\text { Deviation }\end{array}$} & \multirow{3}{*}{$\begin{array}{l}\text { Std. Error } \\
\text { Mean }\end{array}$} & \multirow{2}{*}{\multicolumn{2}{|c|}{$\begin{array}{c}95 \% \text { confidence interval } \\
\text { of the difference }\end{array}$}} & \multirow[b]{3}{*}{$\mathrm{T}$} & \multirow[b]{3}{*}{ Df } & \multirow[b]{3}{*}{ Sig.(2-tailed) } \\
\hline & & & & & & & & \\
\hline & & & & Lower & Upper & & & \\
\hline $\begin{array}{l}\text { Cont. Group pre- } \\
\text { post }\end{array}$ & -4.9667 & 4.39814 & .80299 & -6.6090 & -3.3244 & $\begin{array}{c}- \\
6.185\end{array}$ & 29 & .000 \\
\hline
\end{tabular}

Table 8 shows a significant difference between the control group learners' SRQ scores in the pretest and posttest [t (29) $=-6.18, \mathrm{p}=.000$ (two-tailed)]. The mean increase in SRQ scores is -4.96 with a $95 \%$ confidence interval ranging from 6.60 to -3.32 . Thus, posttest scores show that the learners' self-regulation skill has also improved in the control group. It should be noted that although there is an increase between the students' SRQ scores from pretest to posttest in the control group, this increase is much less than that of the learners' SRQ scores from pretest to posttest in experimental group. In other words, as shown in Table 7, the difference between mean of pretest and mean of posttest is -30.06 scores in the experimental group while according to Table 8, the difference between mean of pretest and mean of posttest is 4.96 scores in control group showing that after a five-month study, the learners' self-regulation skill in experimental group improved much more than the learners' self-regulation skill in control group. Consequently, although traditional pedagogy is effective in improving the learners' self-regulation skill, it is not as effective as critical pedagogy in doing so.

Table 9. Independent T-Test Pretest of SRQ by groups

\begin{tabular}{|c|c|c|c|c|c|c|c|c|c|}
\hline & $\begin{array}{c}\text { Lev } \\
\text { Te } \\
\text { Equa } \\
\text { Var }\end{array}$ & $\begin{array}{l}\text { ne's } \\
\text { for } \\
\text { ty of } \\
\text { nces }\end{array}$ & \multicolumn{7}{|c|}{ t-test for Equality of means } \\
\hline & \multirow[b]{2}{*}{$\mathrm{F}$} & \multirow[b]{2}{*}{ Sig. } & \multirow[b]{2}{*}{$\mathrm{T}$} & \multirow[b]{2}{*}{ Df } & \multirow[b]{2}{*}{$\begin{array}{l}\text { Sig.(2- } \\
\text { tailed) }\end{array}$} & \multirow{2}{*}{$\begin{array}{c}\text { Mean } \\
\text { difference }\end{array}$} & \multirow{2}{*}{$\begin{array}{l}\text { Std. Error } \\
\text { Difference }\end{array}$} & \multicolumn{2}{|c|}{$\begin{array}{l}95 \% \text { confidence } \\
\text { interval of the } \\
\text { difference }\end{array}$} \\
\hline & & & & & & & & lower & Upper \\
\hline $\begin{array}{l}\text { Ex.-Co. Equal } \\
\text { variances }\end{array}$ & .001 & .974 & -.356 & 58 & .723 & -2.93 & 8.250 & $\begin{array}{c}- \\
19.448\end{array}$ & 13.582 \\
\hline $\begin{array}{l}\text { assumed } \\
\text { Equal }\end{array}$ & & & -.356 & 57.999 & .723 & -2.93 & 8.250 & - & 13.582 \\
\hline $\begin{array}{l}\text { variances } \\
\qquad \text { not assumed }\end{array}$ & & & & & & & & 19.448 & \\
\hline
\end{tabular}


Table 9 shows that the observed $t$-value (-.35) at 58 degrees of freedom is lower than the critical t-value, (2.02) at .05 level of confidence, therefore the difference between means of two groups obtained from pretest are not statistically meaningful showing that the two groups are similar prior to the beginning of the treatment $[\mathrm{t}(58)=-.35, \mathrm{p}=.72$ (twotailed)]. Also as Table 9 shows, the magnitude of the means (mean difference $=-2.93,95 \% \mathrm{CI}$ : -19.44 to 13.58 ) is very small.

It should be noted that the two groups were homogenous in terms of their variances on the pretest. As shown in Table 9, the Levene's test for equality of variances $\mathrm{F}=.001$ has a probability of .97 that is much higher than the significance level (.05). That is why the first row of Table 9 "Equal variances assumed" is reported.

Table 10. Independent T-Test Posttest of SRQ by Groups

\begin{tabular}{|c|c|c|c|c|c|c|c|c|}
\hline & $\begin{array}{c}\text { Levene's } \\
\text { Test for } \\
\text { Equality of } \\
\text { Variances }\end{array}$ & \multicolumn{7}{|c|}{ t-test for Equality of means } \\
\hline & \multirow[b]{2}{*}{$\begin{array}{l}\text { F } \\
\text { Sig. }\end{array}$} & \multirow[b]{2}{*}{$\mathrm{T}$} & \multirow[b]{2}{*}{ Df } & \multirow[b]{2}{*}{$\begin{array}{l}\text { Sig.(2- } \\
\text { tailed) }\end{array}$} & \multirow{2}{*}{$\begin{array}{c}\text { Mean } \\
\text { difference }\end{array}$} & \multirow{2}{*}{$\begin{array}{l}\text { Std. Error } \\
\text { Difference }\end{array}$} & \multicolumn{2}{|c|}{$\begin{array}{c}95 \% \text { confidence } \\
\text { interval of the } \\
\text { difference }\end{array}$} \\
\hline & & & & & & & lower & Upper \\
\hline $\begin{array}{l}\text { Ex.-Co. Equal } \\
\text { variances }\end{array}$ & $9.845 \quad .003$ & 3.107 & 58 & .003 & 22.17 & 7.135 & 7.884 & 36.449 \\
\hline $\begin{array}{l}\text { Assumed } \\
\text { Equal }\end{array}$ & & 3.107 & 49.666 & .003 & 22.17 & 7.135 & 7.833 & 36.500 \\
\hline $\begin{array}{l}\text { variances } \\
\text { not assumed }\end{array}$ & & & & & & & & \\
\hline
\end{tabular}

As presented in Table 10, the results of independent t-test on the means of posttest confirm that the observed t-value of (3.1) at 49.66 degrees of freedom exceeds its critical value (2.02) at.05 level of significance. Therefore, it can be asserted that there is a significant difference between the experimental and control groups mean scores on the posttest of SRQ after administration of the CP treatment to the former group [ $\mathrm{t}(49.66)=3.1, \mathrm{p}=.003$ (two-tailed)]. Moreover, as Table 10 shows, the magnitude of the difference in the means (mean difference $=22.17,95 \%$ CI: 7.83 to 36.5 ) is very big.

It should be noted that the two groups are not homogenous in terms of their variances on the post-test. The Levene's test for equality of variances $\mathrm{F}=9.84$ has a probability of .003 (Table 10) which is lower than the significance level .05 . That is why the second row of Table 10 "Equal variances not assumed" is reported.

Thus, it can be concluded that the null hypothesis stating that "critical pedagogy does not have any significant effect on Iranian upper-intermediate EFL learners' self-regulation" was rejected. Consequently, it can be claimed that the treatment (critical pedagogy) the students had in the experimental group was the cause of the significant difference of the learners' SR capacity between the control and experimental groups at their posttest because on one hand, table 9 shows that both of the control and experimental groups were homogeneous at the beginning of the study. On the other hand, table 7 (related to the experimental group) and table 8 (related to the control group) indicate that although the students' self-regulation skill in both groups improved after a five-month study (meaning that both traditional pedagogy and critical pedagogy affected the learners' self-regulation skill), the effect of CP on Iranian upper-intermediate EFL learners' self-regulation is much more significant than the effect of traditional pedagogy.

Cross tabulation of SRQ data are estimated to classify the students into the low, intermediate, and high self-regulation capacity based on their SRQ data.

Table 11. Cross Tabulation of SRQ Data in the Pretest and Posttest of Experimental Group

\begin{tabular}{lllrrrr}
\hline & & \multicolumn{3}{c}{ Cod Exp. Post } & \\
\cline { 3 - 5 } & & & low & intermediate & high & \multicolumn{1}{c}{ Total } \\
\hline Cod & Low & Count & 2 & 10 & 3 & 15 \\
Exp. Pre & & $13.3 \%$ & $66.7 \%$ & $20.0 \%$ & $100.0 \%$ \\
& & \% within COD Exp. & $100.0 \%$ & $90.9 \%$ & $17.6 \%$ & $50.0 \%$ \\
\cline { 2 - 5 } & Intermediate & Count & 0 & 1 & 9 & 10 \\
& & \% within VAR00001 & $.0 \%$ & $10.0 \%$ & $90.0 \%$ & $100.0 \%$ \\
& & \% Within VAR00001 & $.0 \%$ & $9.1 \%$ & $52.9 \%$ & $33.3 \%$
\end{tabular}




\begin{tabular}{rlrrrr}
\hline \multirow{3}{*}{ High } & Count & 0 & 0 & 5 & 5 \\
& \% within COD Exp. & $.0 \%$ & $.0 \%$ & $100.0 \%$ & $100.0 \%$ \\
& \% Within VAR00001 & $.0 \%$ & $.0 \%$ & $29.4 \%$ & $16.7 \%$ \\
\hline \multirow{3}{*}{ Total } & Count & 2 & 11 & 17 & 30 \\
& \% within COD Exp. & $6.7 \%$ & $36.7 \%$ & $56.7 \%$ & $100.0 \%$ \\
& \% Within VAR00001 & $100.0 \%$ & $100.0 \%$ & $100.0 \%$ & $100.0 \%$ \\
\hline
\end{tabular}

As it is clear in Table 11, although half of the learners in experimental group have a low SR capacity at the pretest, more than half of them are at a high level of SR capacity at the posttest. In fact, the results in Table 11 show that at the SRQ posttest in the experimental group, only 2 students (equal to 6.7 percent) are at the low level, 11 students (36.7 percent) are at the intermediate level, and 17 learners (56.7 percent) are at the high level of SR capacity, Thus, it is clear that the learners' SR skill in the experimental group has significantly improved after a five-month treatment. In fact, from the fifteen low level students in the pretest, about eleven students moved into the intermediate level of SR skill, approximately two students ( probably those whose scores were on the border of the intermediate level) moved into the high level, and only two students remained at the low level of SR skill. Also, almost all of the learners who were at the intermediate level of SR at pretest showed high level of SR capacity at the posttest. Therefore, as the results of Table 11 shows, $\mathrm{CP}$ has a significant effect on developing learners' self-regulation skill.

Table 12. Cross Tabulation of SRQ Data in the Pretest and Posttest of Control Group

\begin{tabular}{|c|c|c|c|c|c|c|}
\hline & & & \multicolumn{3}{|c|}{ Cod Cont. post } & \multirow[b]{2}{*}{ Total } \\
\hline & & & low & intermediate & High & \\
\hline Cod & Low & Count & 14 & 1 & 0 & 15 \\
\hline \multirow[t]{8}{*}{ Cont. pre } & & $\%$ within COD Cont. & $93.3 \%$ & $6.7 \%$ & $.0 \%$ & $100.0 \%$ \\
\hline & & $\%$ Within VAR00001 & $100.0 \%$ & $14.3 \%$ & $.0 \%$ & $50.0 \%$ \\
\hline & Intermediate & Count & 0 & 6 & 3 & 9 \\
\hline & & $\%$ within COD Cont. & $.0 \%$ & $66.7 \%$ & $33.3 \%$ & $100.0 \%$ \\
\hline & & \% Within VAR00001 & $.0 \%$ & $85.7 \%$ & $33.3 \%$ & $30.0 \%$ \\
\hline & High & Count & 0 & 0 & 6 & 6 \\
\hline & & $\%$ within COD Cont. & $.0 \%$ & $.0 \%$ & $100.0 \%$ & $100.0 \%$ \\
\hline & & $\%$ Within VAR00001 & $.0 \%$ & $.0 \%$ & $66.7 \%$ & $20.0 \%$ \\
\hline \multirow[t]{3}{*}{ Total } & & Count & 14 & 7 & 9 & 30 \\
\hline & & \% within COD Cont. & $46.7 \%$ & $23.3 \%$ & $30.0 \%$ & $100.0 \%$ \\
\hline & & $\%$ Within VAR00001 & $100.0 \%$ & $100.0 \%$ & $100.0 \%$ & $100.0 \%$ \\
\hline
\end{tabular}

Comparing the results of SRQ at the pretest and posttest of control group, it is found out that there is a difference between the learners' SR skill at the pretest and posttest though the difference was so little. Paying attention to the results of Table 12, it can be understood that among the learners with low level of SR from pretest to posttest, only one learner has probably moved into the intermediate level, and among the learners of intermediate level, approximately three students moved into the high level of SR skill. Thus, although Table 8 shows a significant difference $[\mathrm{t}(29)=$ $6.18, p=.000$ (two-tailed)] regarding the learners' SR capacity between the pretest and posttest of control group, comparing the low, intermediate, and high levels of SR in Table 12 shows that it is hard to use the word "significant difference" between the learners' SR in the pretest and posttest of control group. In fact, although there is a difference between the learners' scores in the pretest and posttest of SRQ of the control group, the difference is hardly found to be significant. Therefore, like CP, traditional pedagogy affected the learners' SR skill, but this effect was not as significant as that of $\mathrm{CP}$.

\section{Conclusions}

CP significantly affected Iranian upper-intermediate EFL learners' writing ability. This finding confirms Motallebzadeh and Askari's (2009) study representing that applying CP affected the development of language ability of Iranian intermediate EFL learners.

The results of this study showed that not only CP but also traditional pedagogy improved learners' self-regulation skills. However, the effect of traditional pedagogy on the learners' self-regulation was not as significant as the effect of CP. This can be implied that any kind of education or pedagogy can lead to self-regulation but CP-oriented education can accelerate and facilitate self-regulation in the language learning process. 


\section{References}

Aghagolzadeh, F., \& Davari, H. (2012). The rationale for applying critical pedagogy in expanding circle countries: The case of Iran. Journal of Language Teaching and Research, 3(5), 973-980. doi:10.4304/j1tr.3.5.973-980

Alsamadani, H. A. (2010).The relationship between Saudi EFL students' writing competence, L1 writing proficiency, and self-regulation. European Journal of Social Sciences, 16(1), 53-63.

Arnaudet, M. L., \& Barrett, M. E. (1990). Paragraph development: A guide for students of English. NJ: Prentice-Hall. Brown, J. M., Miller, W. R., \& Lawendowski, L. A. (1999). The self-regulation questionnaire. In L. VandeCreek \& T. L. Jackson (Eds.), Innovations in clinical practice: A source book (Vol. 17, pp. 281-289). Sarasota, FL: Professional Resource Press. Retrieved from: http://casaa.unm.edu/inst/SelfRegulation\%20Questionnaire\%20\%28SRQ\%29.pdf

Byean, H. (2011). An exploration for glocalizing critical pedagogy in the Korean middle school context: Toward critical co-teaching praxis between local and native-English-speaking teachers (Unpublished master's thesis). University of Wisconsin-River. Retrieved from: minds.wisconsin.edu/bitstream/handle/1793/49173/Byean.pdf

Cuenca-Sanchez, Y. (2008). Self-regulated strategy development through a critical literacy approach: Teaching students with disabilities to write persuasively by understanding the word and the world. Retrieved from: http://mason.gmu.edu/ ycuencas/documents/Literacy\%20course\%20EDRD\%20830/Final\%20Paper\%20Literacy\%20 05.12.08\%20a.pdf

Fredricks, L. (2007). A rationale for critical pedagogy in EFL: The case of Tajikistan. The Reading Matrix, 2(2), 2228.

Freire, P. (1970). Pedagogy of the oppressed. New York: Seabury.

Giroux, H. A. (1981). Ideology, culture, and the process of schooling. Philadelphia: Temple University Press.

Giroux, H. A. (1983). Theory and resistance in education: A pedagogy for the opposition. New York: Bergin \& Garvey.

Graham, S. (2006). Strategy instruction and the teaching of writing: A meta-analysis. In C. MacArthur, S. Graham, \& J. Fitzgerald (Eds.). Handbook of writing research (pp. 187-207). New York: Guilford.

Izadinia, M. (2012). Teacher educators as role models: A qualitative examination of student teachers' and teacher educators' views towards their roles. The Qualitative Report, 17, 1-15. Retrieved from: http://www.nova.edu/ssss/QR/QR17/izadinia.pdf

Jupp, TC, \& Milne, J. (1972). Guided paragraph writing. London: Heinemann Educational Books.

Keesing-Style, L. (2003). The relationship between critical pedagogy and assessment in teacher education. Retrieved from: http://radicalpedagogy.icaap.org/content/issue5 1/03 keesing-style.html

Lesley, T., Hanson, C., \& Zukowski/Faust, J. (2005). New interchange/passages placement and evaluation package. Cambridge: Cambridge University Press.

Majid, F. A. (2007). Self-regulated learning: Effective practices in ESL writing classes. Journal of Language Studies, $3,115-128$.

Mohebi, A., Beykmohammadi, M., \& Farsani, M. A. (2011). On the relationship between Iranian EFL learners' goaloriented and self-regulated learning and their writing performance. International Conference on Languages, Literature and Linguistics, 26, 192-196.

Moreno-Lopez, I. (2005). Sharing power with students: The critical language classroom. Retrieved from: http://radicalpedagogy.icaap.org/content/issue7 2/Moreno.html

Motallebzadeh, k., \& Askari, F. (2009). The effect of critical pedagogy on the development of self-esteem and language ability of Iranian intermediate EFL learners (Unpublished master's thesis). Islamic Azad University, Garmsar, Iran.

Peirce, B. N. (1989). Toward a pedagogy of possibility in the teaching of English internationally: People's English in South Africa. TESOL Quarterly, 23(3), 401-420.

Pennycook, A. (1990). Critical pedagogy and second language education. System, 18(3), 303-314.

Pennycook, A. (1995). English in the world /the world in English. In J. W. Tollefson (Ed.), Power and inequality in language education. Cambridge: Cambridge University Press.

Ruan, Z. (2005). A metacognitive perspective on the growth of self-regulated EFL student writers. Reading Working Papers in Linguistics, 8, 175-202.

Shor, I. (1996). When students have power. In I. Moreno-Lopez (2005), Sharing power with students: The critical language classroom. Retrieved from: http://radicalpedagogy.icaap.org/content/issue7_2/Moreno.html

Wallace, C. (1997). The role of language awareness in critical pedagogy. In L. V. Lier \& D. Corson (Eds.), Knowledge about language. Dordrecht: Kluwer. 